\title{
O Ensino de Ciências na Visão de Professores dos Anos Finais do Ensino Fundamental
}

Binatto, Priscila F. ${ }^{1}$; Martins, Carmen M. De Caro ${ }^{2}$; Duarte, Ana Cristina S. ${ }^{3}$

\section{Resumo}

Apesar dos avanços nas pesquisas na área de ensino de Ciências, é possível observar na maioria das escolas um ensino marcado pela transmissão e recepção de conteúdos fragmentados e descontextualizado da realidade dos alunos. Todavia, entendendo o professor e suas concepções como peça fundamental para um processo de transformação desse quadro, desenvolvemos este trabalho com o objetivo de analisar a visão dos professores de Ciências, dos anos finais do Ensino Fundamental, no que se refere aos processos de ensino-aprendizagem e ao currículo de Ciências. Para tanto, realizamos uma pesquisa quali-quantitativa que teve como instrumentos de coleta de dados a aplicação de um questionário e o registro do memorial descritivo de encontros de formação realizados com o grupo de professores durante três anos. Os resultados apontam para uma concepção próxima dos movimentos de renovação pedagógica, mas ainda dividida e impregnada pelas práticas tradicionais.

Palavras chave: ensino de ciências, visões de professores, currículo

\footnotetext{
${ }^{1}$ Universidade Estadual do Sudoeste da Bahia (UESB). Mestranda do Programa de Pós-Graduação em Educação Científica e Formação de Professores. Rua José Moreira Sobrinho, s/n. Jequiezinho. CEP: 45206-190 Jequié, BA, Brasil. priscilabinatto@yahoo.com.br

${ }^{2}$ Universidade Federal de Minas Gerais (UFMG). Diretora do Colégio Técnico da UFMG (COLTEC). Avenida Presidente Antônio Carlos, 6627. Pampulha. CEP: 31270-901 Belo Horizonte. MG, Brasil. carmendecaro@ufmg.br ${ }^{3}$ Universidade Estadual do Sudoeste da Bahia (UESB). Docente do Programa de Pós-Graduação em Educação Científica e Formação de Professores. tinaduarte2@gmail.com
} 


\section{Summary}

Despite advances in research in science teaching, we can observe at schools a teaching marked by transmission and reception of fragmented contents out of the students' reality. However, understanding the teacher and his views is critical to transformation that framework. This study aimed to analyze the vision of science teachers, of the final years of primary education, about the processes of teaching, learning and the science curriculum. So, we conducted a qualitative and quantitative research that had the instruments to collect data a questionnaire and record descriptive history of continuing education meetings conducted with the group of teachers between the years 2009 and 2011. Results indicate a next design of pedagogical renewal movements, but still divided and permeated by traditional practices.

Keywords: science teaching, conceptions of teachers, curriculum 